by Adam Lajczak ${ }^{l}$,Wlodzimierz Margielewski ${ }^{2}$, Zofia Raczkowska ${ }^{3}$ Jolanta Swiechowicz $^{4}$

\title{
Contemporary geomorphic processes in the Polish Carpathians under changing human impact
}

\author{
${ }^{1}$ Pedagogical University, Institute of Geography, 2 Podchorazych Str., 30-084 Cracow, Poland. E-mail: alajczak@o2.pl \\ ${ }^{2}$ Polish Academy of Sciences, Institute of Nature Conservation, 33 A. Mickiewicza Ave., 31-120 Cracow, Poland \\ ${ }^{3}$ Polish Academy of Sciences, Institute of Geography and Spatial Organization, 22 Sw. Jana Str., Cracow, Poland \\ ${ }^{4}$ Jagiellonian University in Krakow, Institute of Geography and Spatial Management, 7 Gronostajowa Str., 30-387 Cracow, Poland
}

The paper presents activity of contemporary geomorphic processes in the Polish Carpathians, taking into account human impact on relief transformation in the past several centuries.

Landsliding in the flysch Carpathians is a principal process in slope transformation, posing the most serious threat to man, both in the mountains and the foothills. On the other hand, unsuitable housing on slopes initiates mass movements, frequently with catastrophic consequences. Land use changes, in particular deforestation, have over the past 200 years fostered intensive slopewash and linear erosion, with this playing an important role in shaping foothill relief. Following changes in land use and channel regulation initiated at the beginning of the 20th century, a tendency to river bed deepening prevails. Moreover, floods, and not only extreme instances, continue to pose a threat to man, with their effects enhanced by housing in floodplain areas.

A tendency consisting in the reduction of arable land and an increase in grassland and forest area, observed over the past two decades, will lead to a gradual limitation of slope-wash and wind erosion as well as a simultaneous increase in linear erosion on slopes and river bed deepening.

\section{Introduction}

Geomorphic processes, both secular and - more spectacular as far as their effects are concerned - extreme or catastrophic, are continually transforming the landscape of the Polish Carpathians, albeit with varying intensity. Beyond climate and geological setting, the results of such processes depend on type of relief. Starkel (1972) distinguished five relief types in the Carpathians: high mountains, middle mountains, low mountains and high foothills, middle and low foothills, and valley bottoms (Fig. 1A and 1B). The new concept of the influence of geological structure on Carpathian relief zonation (Jankowski and Margielewski, 2012) allowed for a reduction in the number of relief types to four: high mountains, middle and low mountains, foothills (including high foothills) and valley bottoms.
The Polish Carpathians are relatively densely populated (127 persons $/ \mathrm{km}^{2}$ ), and more than $65 \%$ of the population live in rural areas (Dlugosz and Soja, 1995). For this reason man exerts a strong influence on the course of geomorphic processes, but recent processes and their effects also pose a threat to man. According to Slaymaker (2010), human activity is a key driver in present-day landscape evolution in mountain areas.

The aim of this paper is to present such mutual relationships within areas showing four types of relief, indicating the most important process, type of geomorphic hazard and type and effect of human influence on relief transformation, as well as tendencies in these interrelationships under a changeable climate over the past several centuries, particularly with regard to the last 200 years.

In this period, from the $13^{\text {th }}$ century onwards, important changes occurred in the intensity of various types of anthropopressure (extent and duration of human impacts) in the Polish Carpathians. Some of these gained in intensity (for instance river channel regulation, construction works both on slopes and in valley bottoms, increasing road density and remedial works), while others fell in importance (such as agriculture since the mid-20 ${ }^{\text {th }}$ century) or disappeared entirely (pasturing). All of these factors resulted in increased forestation (Lach and Wyzga, 2002; Kozak et al., 2007). In the western part of the Polish Carpathians, human impact on the intensity of geomorphic processes has tended to increase, while in the eastern part it halted temporarily owing to the depopulation of this area in the mid- $20^{\text {th }}$ century for political reasons.

The human role in landform evolution and modification of geomorphic processes has been a subject of increasing attention in geomorphic literature (e.g. Nir, 1983; Goudie 2006; Gregory, 2006). Many papers focus on human modification of particular geomorphic processes and landforms, for example fluvial (Brooks, 1988; Bravard and Petts, 1996; Wohl, 2006) or particular relief type, e.g. mountains (Messerli et al., 2000; Remondo et al., 2005; Slaymaker and EmbletonHamann, 2009).

\section{History: progress and regress of human impact on the Carpathians in recent centuries}

The types of human impact that have affected relief and intensity of geomorphological processes in the Polish Carpathian Mountains includes: (1) deforestation, human settlement, agriculture (valley floors, later slopes), since the $13^{\text {th }}$ century (Gerlach, 1966; Adamczyk, 1978; Raczkowska et al., 2012); (2) animal grazing (mainly sheep in 

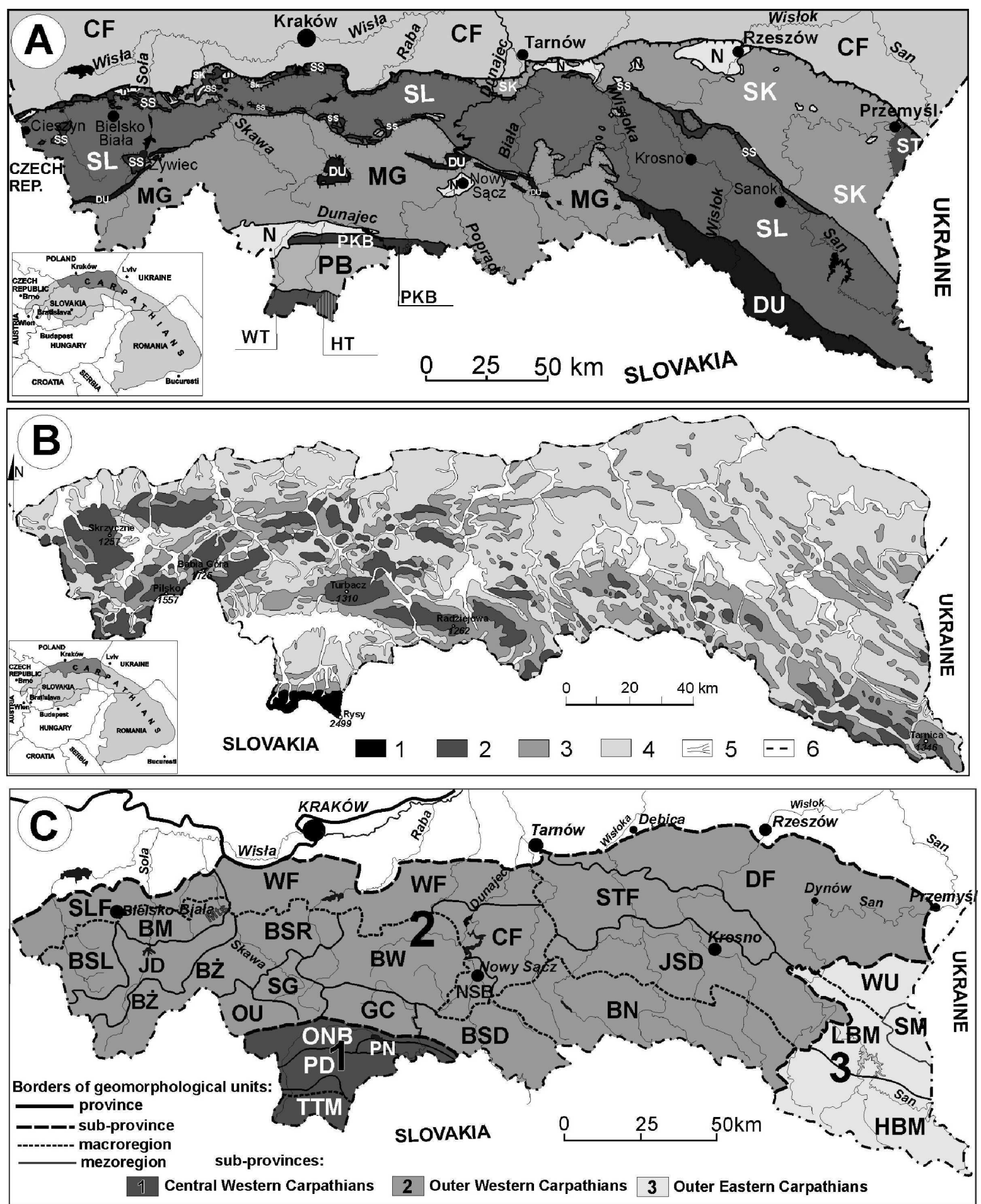

Figure 1. Polish Carpathians: A - geology (after Zytko et al., 1989): symbol explanation: Inner Carpathians: WT - Western Tatra Mts; HT - High Tatra Mts., PB - Podhale Basin; PKB: Pieniny Klippen Belt; Outer Carpathians: MG - Magura Unit; DU - Dukla Unit and their equivalent; SS - Sub-Silesian Unit; SL-Silesian Unit; SK-Skole Unit; ST - Stebnik Unit; CF - Carpathians Foredeep; N-Neogene deposits on flysch. B - types of relief in the Carpathians (after: Starkel, 1972) 1 - high mountains; 2 - middle mountains; 3 - low mountains and high foothills; 4 - middle and low foothills; 5 - bottom of valleys; 6-Carpathians boundary. C-geomorphological units of the Polish Carpathians (after: Starkel, 1972; Gilewska, 1986). Symbol explanations: 1 - Central Western Carpathians: TTM - Tatra Mts.; PD - Podhale; ONB - Orawa-Nowy Targ Basin; PN - Pieniny Mts.; 2 - Outer Western Carpathians: BSL - Beskid Slaski Mts.; BM - Beskid Maly Mts., JD - Jablonkow Depression; BZ - Beskid Zywiecki Mts.; BSR - Beskid Sredni Mts., OU - Orawa Upland; SG - Sieniawa Gate; BW - Beskid Wyspowy Mts.; GC - Gorce Mts.; BSD - Beskid Sadecki Mts.; BN - Beskid Niski Mts.; JSD - JasloSanok Depression; DF - Dynow Foothills; STF - Strzyzow Foothills, CF - Ciezkowice Foothills; NSB - Nowy Sacz Basin;WF - Wieliczka Foothills; SLF - Silesian Foothills; 3 - Outer Eastern Carpathians: HBM - High Bieszczady Mts., LBM - Low Bieszczady Mountains; SM - Slonne Mts., WU - Wankowa Upland. 
forest clearings), since the $15^{\text {th }}$ century (Mirek and Piekos-Mirek, 1979); (3) forest management (mixed forests replaced with spruce monocultures at lower elevations during the $19^{\text {th }}$ and early $20^{\text {th }}$ centuries); later efforts to restore mixed forests; increased forest cover since the 1950s (Raczkowska et al., 2012); (4) mining (stone quarries, gravel extraction, oil extraction), since the $19^{\text {th }}$ century (Raczkowska et al., 2012); (5) glass-making and steel production, locally $\left(15^{\text {th }}-19^{\text {th }}\right.$ centuries) (Raczkowska et al., 2012); (6) large-scale potato farming in the $19^{\text {th }}$ and $20^{\text {th }}$ centuries (Klimek and Trafas, 1972; Raczkowska et al., 2012); (7) transportation infrastructure (a large number of dirt roads and forest roads; railroads since the early $20^{\text {th }}$ century; expansion and modernization of roads for automobiles since the 1950s) (Froehlich and Slupik, 1986); (8) construction of buildings on slopes (large houses since the 1950s; weekend houses since the 1990s) (Raczkowska et al., 2012); (9) river and stream regulation and dams ( $20^{\text {th }}$ century), river shipping (late $19^{\text {th }}$ and early $20^{\text {th }}$ centuries) (Wyzga, 1993; Lajczak, 2006; Krzemien, 2003); (10) summer tourists ( $20^{\text {th }}$ century) and winter tourists (since the 1930s) (Lajczak, 2002).

The most rapid anthropogenic relief changes in the Polish Carpathians have occurred in the past 200 years. All of the forms of human impact listed above came to exert pressure on Carpathian relief during this period (Mirek and Piekos-Mirek, 1979; Raczkowska et al., 2012). Some forms of human impact grew stronger while others remained weak. Today the most active forms of human impact in the Polish Carpathians include building and road construction and tourism. Declining forms of human impact include sheep herding, mining and agriculture. Glassmaking and steel production no longer take place. The abandonment of agriculture on mountain slopes in the region has led to mountain slope reforestation (Fig. 2). The eastern part of the Polish Carpathians underwent depopulation in the late 1940s resulting in almost $100 \%$ increase in the forest cover (Lach and Wyzga, 2002; Wolski, 2007; Nowak, 2012). Reforestation in the western part of the Polish Carpathians began on a smaller scale in the 1990s (Ostafin, 2009; Bucala, 2012). The greatest human impacts on Carpathian relief have been from rock quarrying, dam construction (delta formation in reservoirs), house construction on valley floors and slope agriculture at lower elevations (Raczkowska et al., 2012). The effects of human impact on relief decrease significantly at higher elevations. While some types of human activity have declined in the region over the years, the relief transformation caused by these is still visible.

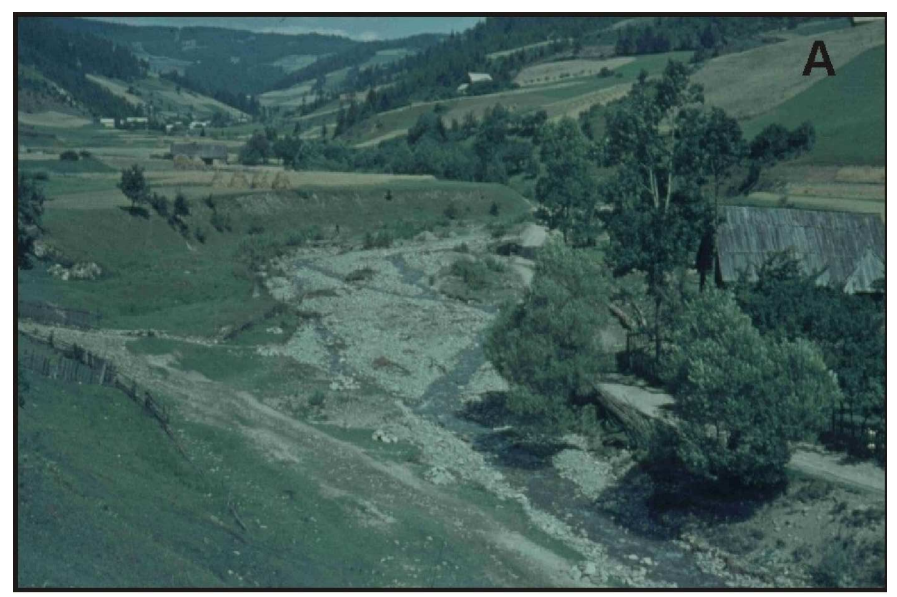

Figure 2. Transformation of landscape of small Carpathian valley during last forty years. A - year 1968, B - year 2008. Note increased range of forest and changes in stream channel pattern (photo $A-M$. Niemirowski; photo B-A. Bucala).

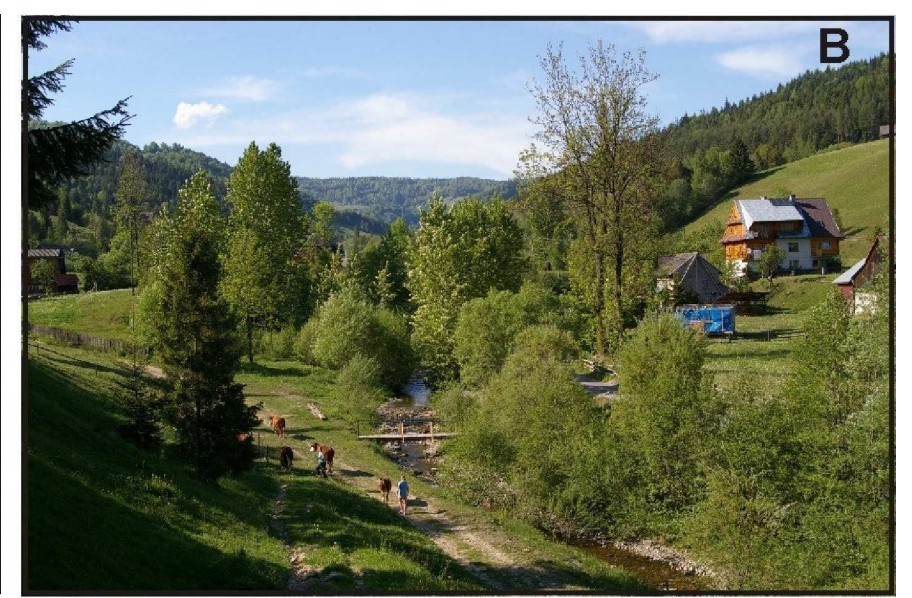

\section{Geological setting}

The Polish Carpathians are divided into the Inner Carpathians (consisting of the Tatra Mountains and the Podhale Basin) and the Outer Carpathians (also called the Flysch Carpathians), separated by the Pieniny Klippen Belt (Fig. 1A, Ksiazkiewicz, 1972). The Tatra Mountains are composed of a central crystalline core and a cover of sedimentary rocks. The core, formed of intrusive carboniferous granitoids and metamorphic rocks (gneisses, amphibolite, metamorphic shale), is rimmed by allochthonous High Tatric Nappes and Sub-Tatric Nappes, consisting of quartzites, dolomites, limestones, marls, shales and sandstones of the Triassic-Middle Cretaceous age. The Podhale Basin is filled with conglomerates, nummulitic limestones, and Podhale flysch formations (shales and sandstones of the Palaeogene period), 2,500 m thick within a widespread syncline.

The Pieniny Klippen Belt, a narrow but deeply rooted tectonic structure, is formed of Upper Cretaceous-Palaeogene deposits: limestones, radiolarites, marls, sandstones and shales (Birkenmajer, 1986). Occurring along the boundary of the Pieniny Klippen Belt and the Outer Carpathians are andesite intrusions of the Miocene period.

The Outer (Flysch) Carpathians are formed of flysch sediments (and, occasionally, marls and hornstones) of the Late Jurassic-Early Miocene age (Ksiazkiewicz, 1972; Oszczypko, 1995). Flysch rocks, strongly folded, jointed and faulted, form several nappes/units (the Magura, Dukla, Silesian, Sub-Silesian, Skole and Stebnik Units) thrust over each other horizontally toward the north. On the northern foreland of the Carpathians, a large tectonic depression called the Carpathian Foredeep formed and became filled with Miocene deposits (Fig. 1A) (Oszczypko et al., 2006).

In the Tatras and the Pieniny, coarse debris predominate in slope cover, while in the Podhale Basin and the Outer Carpathians slope cover is mainly formed of silt and clays. The relief of the Carpathians is apparently conditioned by geological structure, both lithology and tectonic (Fig. 1A and 1B) (Starkel, 1960, 1972). However, landform transformation in each type of relief (high mountains, middle and low mountains, foothills and valley bottoms) is a result of processes induced by climate and human activity (Fig. 3).

\section{High mountains}

High mountains with relief remodelled by glaciers include the 


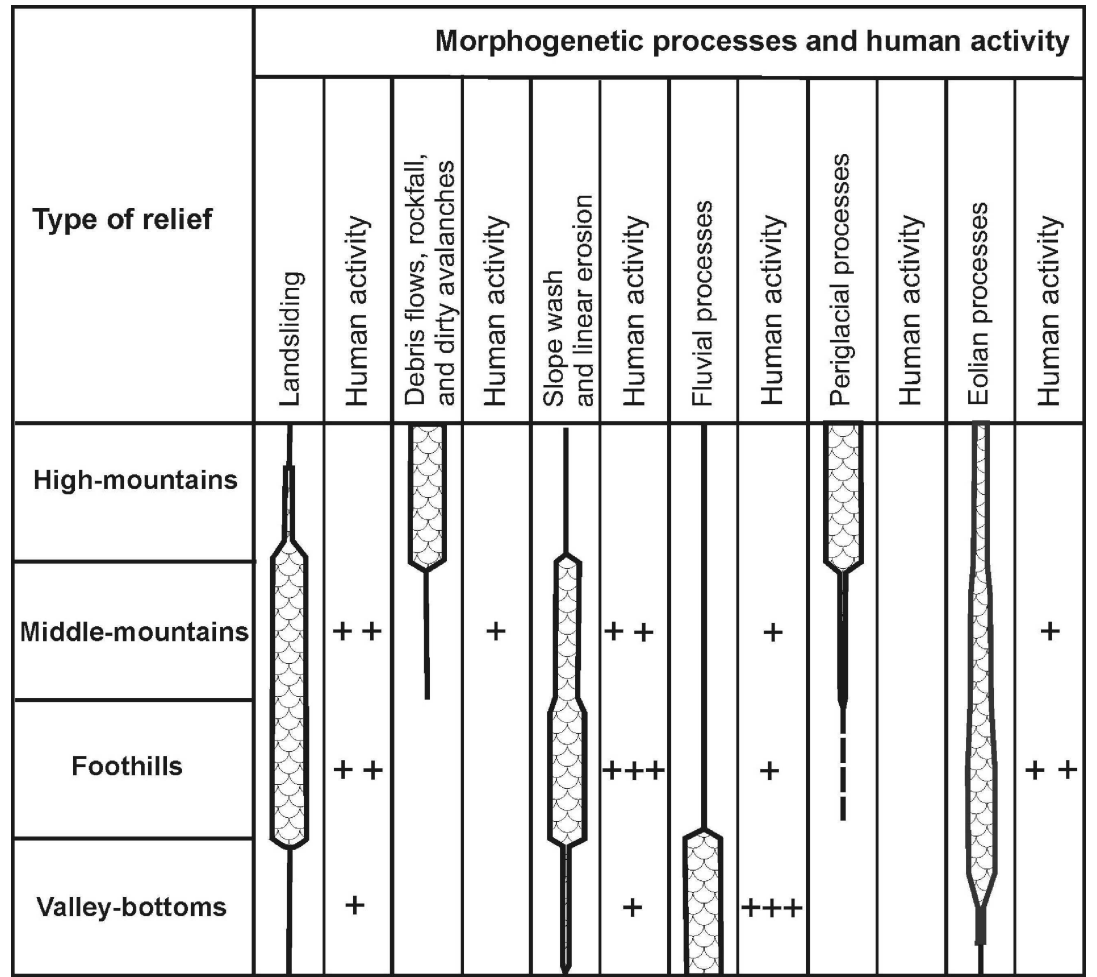

Figure 3. Significance of recent geomorphic processes and their interaction with man in the recent relief transformation in the Polish Carpathians. Strength of interaction between man activity and particular process is marked by "+". No sign insignificant, “+”- week, “++”- strong, “+++”- very strong.

Tatra Mts. (2,655 m a.s.1.) in the Inner Carpathians and, in the Flysch Carpathians, the topmost part of the Babia Gora Mt. massif (1,725 m a.s.1.) (Fig. 1A and 1C). Occurring in these massifs, above the upper timber line, is the climatic periglacial zone, with isolated patches of permafrost in the Tatras (Moscicki and Kedzia, 2001; Gadek et al., 2009), in which periglacial processes dominate (Fig. 3, Jahn, 1958; Raczkowska, 2008). The role of other morphogenetic processes is differentiated depending on type of slope, geoecological altituderelated belts and bedrock lithology. Chemical denudation is common, being most intense upon carbonate bedrock in the forest belt in the Tatras (Kotarba, 1971). High-mountain crests and rocky slopes tend to retreat and become lowered due to frost weathering and rockfall, supplying material which overlies lower talus slopes (Kotarba et al., 1987 ; Raczkowska, 2008). The intensity of rocky slope retreat is 0.001 $1.0 \mathrm{~cm} / \mathrm{yr}$, while that of debris slope accretion is $0.1-10.0 \mathrm{~cm} / \mathrm{yr}$ (Raczkowska, 2008). Moreover, the slopes are undergoing dissection by chutes and are being modelled by corrasion, debris flows and avalanches (Kotarba et al., 1987). The latter, beyond gravitational and periglacial processes, play a very important role in transformation of talus slopes. Slopes mantled by weathering covers are modelled by cryo-nival and gravitational (creeping) processes, which lead to slow $(1.7-2.0 \mathrm{~cm} / \mathrm{yr})$ but relatively uniform translation of slope cover over the entire slope surface (Kotarba et al., 1987; Raczkowska, 1995, 2008), as well as by erosional (Kotarba et al., 1987; Krzemien, 1991) and aeolian processes (Izmailow, 1984). The resulting nival, erosion or deflation niches foster slope fragmentation (Kotarba et al., 1987; Raczkowska, 1995). The development of such niches has been intensified by human impact in the past 200 to 300 years (Kaszowski et al., 1988). This impact was particularly strong at the end of the $19^{\text {th }}$ century and in the first half of the $20^{\text {th }}$ due to mining, the iron industry and intensive sheep grazing, which resulted in deforestation and destruction of continuous covers of alpine grass and dwarf pine communities (Mirek, 1996). Almost 20 years after sheep grazing was abandoned, erosional processes had slowed (Jahn, 1979), while anthropogenic landforms such as quarries, mine shafts and roads remained. Moreover, monoculture forests introduced in place of natural forest communities are conducive to erosion involving tree toppling linked with foehn or bora-type winds (Fig. 4, Kotarba, 1970).

During periods of average meteorological conditions, relief changes in the valley bottoms are insignificant and restricted to stream beds (Kaszowski, 1973; Krzemien, 1991). Minor modifications in the stream beds are due mainly to lateral erosion during floods (Krzemien, 1991), whereas important and permanent changes, although confined to short stream reaches only, tend to post-date extreme floods (Kaszowski, 1973; Kotarba, 1999).

Debris flows, dirty avalanches and rockfalls play the most important role in contemporary transformation of the morphology of the Tatras, by remobilising and transporting large quantities of debris material and shaping new landforms (Figs. 3 and 5, Kotarba, 1992, 1995, 1997; Raczkowska, 2008). Most significant among rapid mass movements are debris flows, which tend to occur more frequently and widely than the other processes (Kotarba, 1995; Raczkowska, 2008; Raczkowska et al., 2012). The debris flows are able to carry a load ranging from several to several tens of thousands of cubic metres of weathering material from the interfluves to valley bottoms (Kotarba et al., 1987; Krzemien, 1991; Kotarba, 1992). This activity produces newly-formed gullies (Fig. 5), several metres deep and several hundred metres long, and debris flow levees, more than $1 \mathrm{~m}$ in height, or it markedly changes morphometric parameters of preexisting landforms. The resulting changes of relief are linear (debris flows, avalanches) or point-like (rockfalls) in nature (Krzemien, 1991; Kotarba, 1992, 1997). According to results of lake sediment analysis and lichenometric studies, the activity of both debris flows and rockfalls was stronger during the Little Ice Age (Kotarba, 1995).

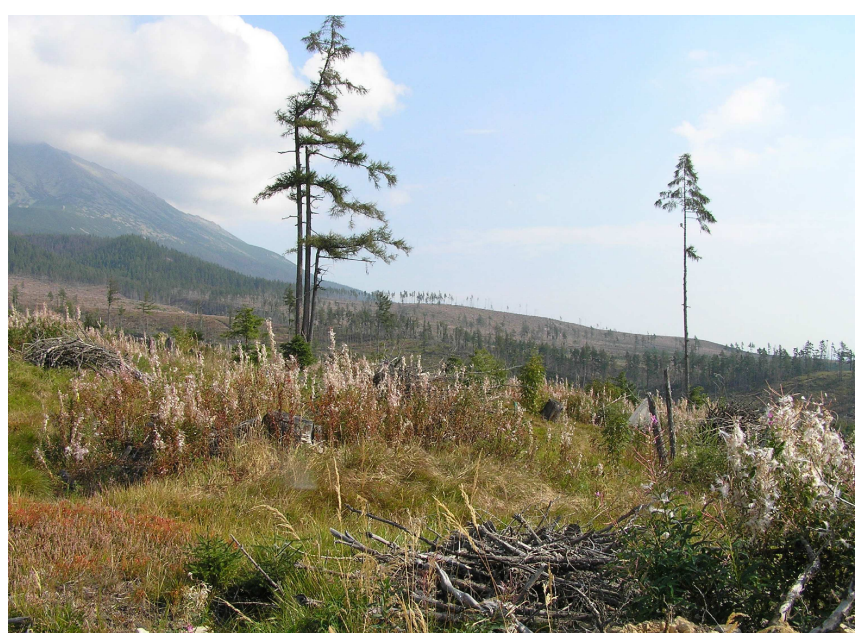

Figure 4. Effects of bora wind in the forest zone of the Tatras, southern slopes, Slovakia (photo Z. Raczkowska). 


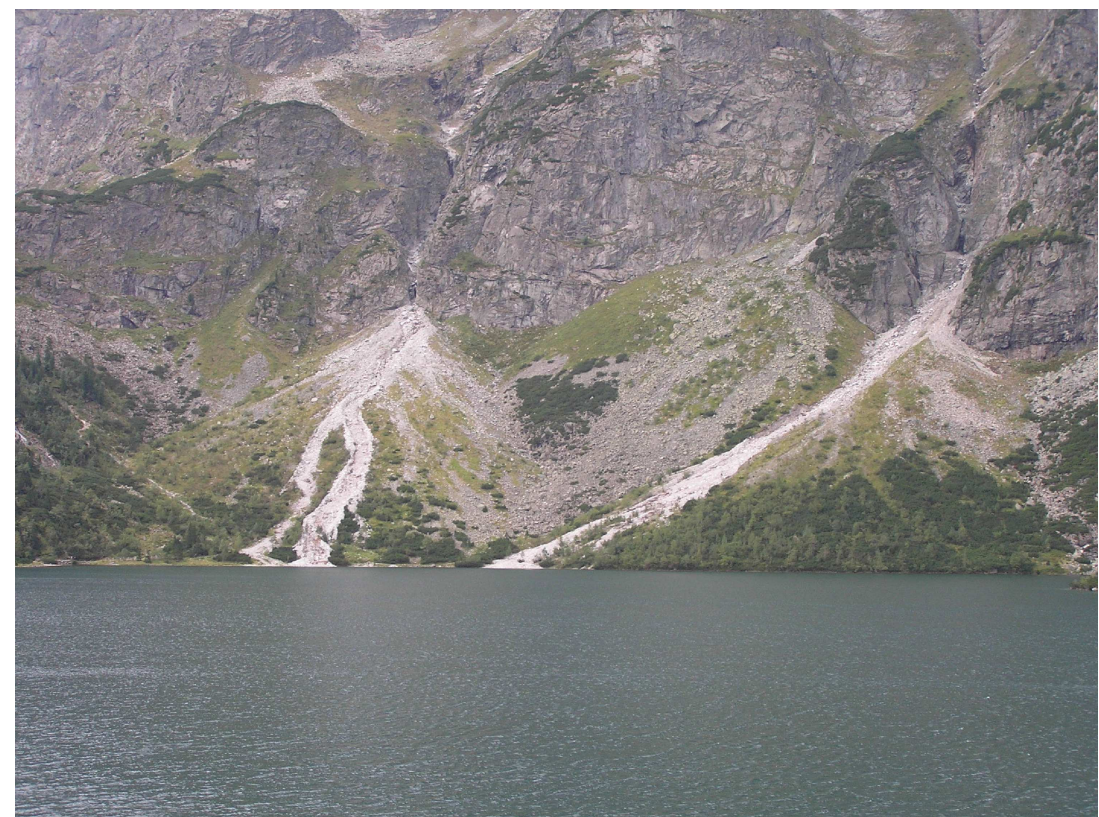

Figure 5. Debris flows, triggered by precipitation of intensity $41 \mathrm{~mm} / \mathrm{hour}$ at 23 August 2010, form new gully (first on the left on the photo) and strongly remodelled existing debris flow gullies on talus slopes above the Morskie Oko lake in the Tatra Mts. (photo Z. Raczkowska)

Rapid mass movements, with the exception of avalanches, do not pose a serious threat to man in that high-mountain areas are, at present, located within uninhabited national parks. Such areas are visited by climbers, tourists and skiers, more rarely by woodcutters. In the past several decades, human-induced relief changes have tended to concentrate along tourist trails and be linear in nature. These changes are related chiefly to summer tourist activity, while climbing and skiing are of minor importance. Tourist trails tend to become deeper and wider, especially in parts where protective pavements of stones have been destroyed. Increased activity in geomorphic processes is seen in zones of up to several metres in width accompanying tourist trails (Czochanski, 2000) at sites at which vegetation cover has been destroyed.

In the forest belt, slope rills develop owing to the repeated dragging of felled tree trunks. These rills are gradually erased by natural processes, when exploitation ceases (vide Raczkowska, 2008).

\section{Middle and low mountains}

Middle mountains (800-1,300 m a.s.1.) with steep slopes (> 30\%) developed in the Carpathians on resistant thick-bedded flysch sandstones and include both tight mountain groups (Beskid Slaski and Zywiecki, and Beskid Sadecki) and isolated ridges of the Beskid Wyspowy and Bieszczady Mts. with a variation of relief energy of 400-800 m (Fig. 1A and 1C). Low mountains tend to occur on the margins of middle mountains or represent isolated monadnock ridges of steep slopes and a variation of relief of 200-400 m, rising above depressions cut into weakly resistant flysch strata (e.g. the Beskid Niski Mts.) (Starkel, 1972). The slopes and valley sides are mantled by slope cover, the thickness of which in the middle mountains is relatively small $(70-80 \mathrm{~cm})$ and increases only slightly on flat piedmont slopes (Kacprzak, 2002-03).

Mass movements (chiefly landslides), triggered by heavy rainfall, play a principal part in slope transformation in the middle and low mountains (Zietara, 1968; Kotarba, 1986; Gorczyca, 2004). Another important morphogenetic process is linear erosion which leads to deepening of river valleys, cart roads and wood cutting trails, resulting sometimes in abundant delivery of weathered material into river beds (Fig. 3). Leaching, suffosion and windinduced toppling of trees are less important. In addition, slope-wash on forested and meadow-covered slopes of the Beskidy Mts. is negligible.

Under present-day climatic conditions and following deforestation, the slopes of the Polish Flysch Carpathians are dominated by shallow landslides formed in slope cover. However, in the course of extreme rainfall numerous shallow rocky-weathering landslides are formed on forested slopes of the middle and low mountains. These partly reach bedrock strata. Erosional deepening and widening of valley bottoms during floods as well as saturation of bedrock and weathering cover by precipitation waters initiate numerous mass movements which lead usually to minor changes in the relief of slopes of the middle and low mountains (Fig. 6.1, Zietara, 1968; Gorczyca, 2004).

The increasing extent of built-up areas and the related development of transport and construction infrastructure on slopes in the past several decades have led to slope overloading, undermining and changing hydrological conditions. As such, the destructive impact of mass movements on the human economy is gradually increasing. Most catastrophic is reactivation of pre-existing landslides by new periods of mass movements. Such repeated transformations of individual landforms by mass movements were observed in years including 1958-60, 19972002 and 2010 (Zietara, 1968; Bajgier-Kowalska and Zietara, 2002; Poprawa and Raczkowski, 2003; Bajgier-Kowalska, 2004). A poorly planned increase in built-up areas upon landslide-prone slopes, sometimes previously affected by mass movements (vide BajgierKowalska, 2004), leads during extreme rainfall to initiation of landslides resulting in extensive destruction to both housing and related communications infrastructure. A peculiar feedback is to be observed: initiation and further development of mass movements, destructive to the human economy, are most frequently triggered anthropogenically (Zietara, 1968; Bajgier-Kowalska, 2004). Recent studies indicate that, in the Carpathians, the majority of the most destructive landslides originated as a result of direct or indirect human activity (Nemcok, 1982; Kotarba, 1989; Poprawa and Raczkowski, 2003; Bajgier-Kowalska, 2004).

A good example of extremely unsuitable construction planning in mountain areas is provided by Lasnica near Lanckorona (Wieliczka Foothills) where, following intensive rainfall in May 2010, 34 houses were seriously damaged. These houses were located in an area in which in July 1960 a landslide destroyed 15 houses and damaged a further nine (largely wooden at that time) (Zietara, 1969). Similarly, a landslide at Lachowice (Beskid Makowski Mts.), originating in July 2001, destroyed 15 houses located on a pre-existing landslide (Fig. 6.3) (Bajgier-Kowalska, 2004; Oszczypko et al., 2002). The most extensive recent landslide at Klodne near Limanowa (Beskid Wyspowy Mts.), reactivated at the beginning of June 2010, also destroyed 17 houses built upon its surface (Fig. 6.2 A-C). Beyond catastrophic rainfall, reactivation was determined by slope overloading related to newly-constructed buildings situated in the uppermost part 

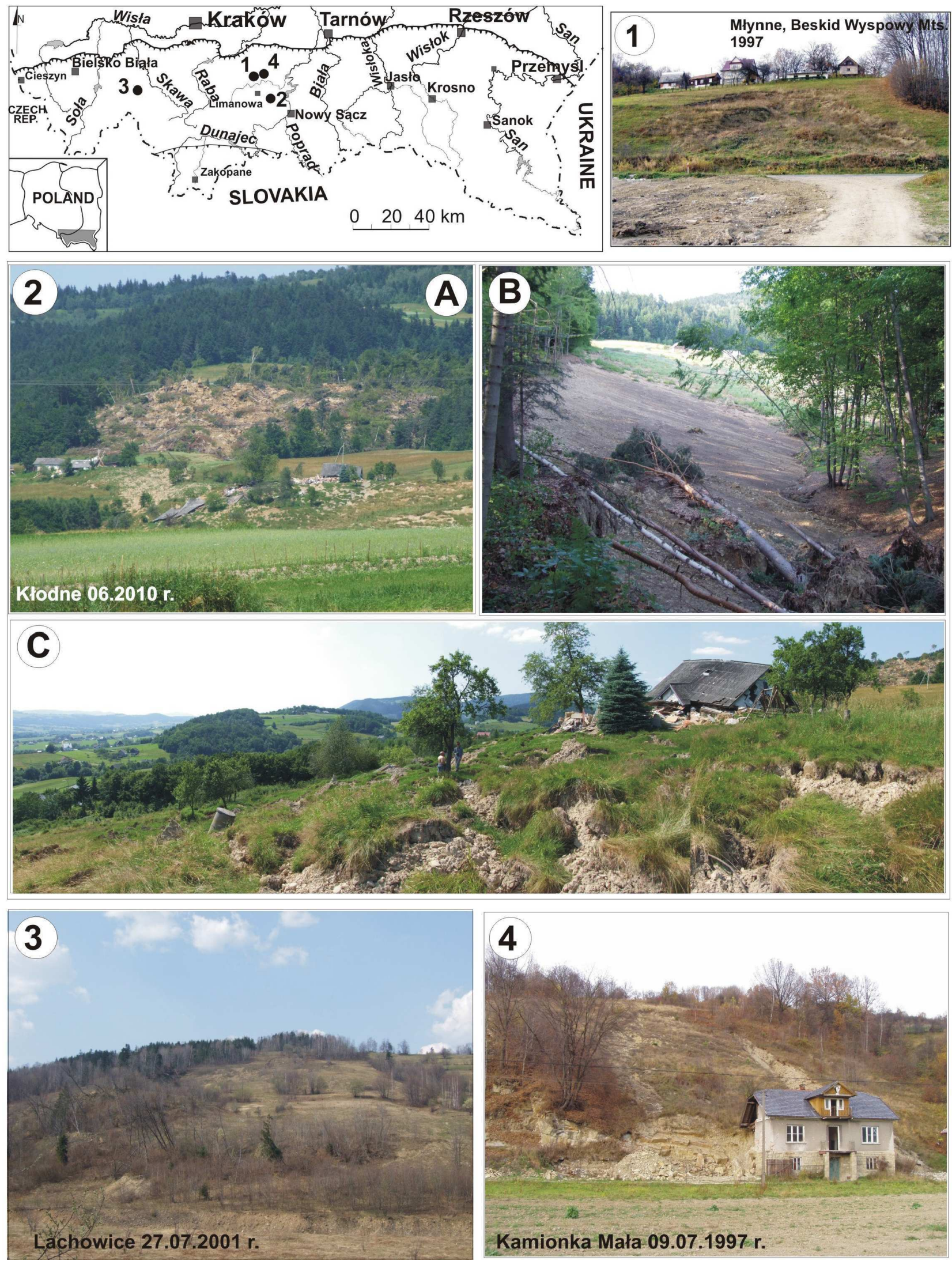

Figure 6. Examples of recent landslides transforming slope relief of catastrophic impact on economy: 1 - small weathering landslide in Mlynne (Beskid Wyspowy Mts.), transformed over-road area (July 1997), 2 - catastrophic landslide at Klodne (Beskid Wyspowy Mts., June 2010): A - vast colluvial swell and destroyed buildings; B - slip surface exposed on ground surface; $C$ - pushed colluvial swell with destroyed buildings in lower parts of the landslide; 3-catastrophic landslide in Lachowice (Beskid Makowski Mts), in July 2001; 4 -small landslide at Kamionna on the Lososina River valley side, in July 1997, which destroyed a house (photo W. Margielewski) 
of the landslide zone. Gravitational sliding was also fostered by a dip in bedrock strata parallel to slope inclination. In some cases, landslides have tragic consequences: in July 1997 a small landslide at Kamionna near Limanowa (Beskid Wyspowy Mts.) resulted in the destruction of a part of a house in which one resident died (Margielewski et al., 2008) (Fig. 6.4). Many landslides develop also in marginal zones of water reservoirs, both due to changes in hydrogeological conditions and through abrasion at the reservoir shore.

Beyond the clearly serious economic losses, contemporary mass movements (frequently anthropogenic) may also lead to minor relief transformation by steepening or smoothing of geomorphic escarpments, broadening and minor changes in the shape of river valleys, slight retreat of valley head niches and the formation of an undulating slope profile (Zietara, 1968; Kotarba, 1986; Gorczyca, 2004; Margielewski et al., 2008). These processes are, however, restricted to very small areas (Fig. 6). The Klodne and Lachowice landslides mentioned above produced, beyond large-scale destruction, significant relief transformation of isolated slopes (Fig. 6.2 and 6.3). Nevertheless, overall transformation of slopes in the Beskidy Mts. occurs only within a longer cycle (of thousands of years) leading, together with other denudation processes (e.g. erosion), to retreat of valley heads, elongation of river valleys, shaping of incipient tributary valleys and, finally, the formation of concave-upwards landslide slope profiles (Starkel, 1960; Zietara, 1968; Kotarba, 1986). In general, contemporary landslides induce other denudation processes, such as creeping, flows, slopewash, suffosion, erosion and weathering (Zietara, 1968). The dominant role of mass movements in shaping the Carpathian landscape is confirmed by a detailed landslide inventory, including recent landforms, which takes into account the number, area and activity classes of landslides. This inventory is currently being conducted on 1:10,000 topographic maps, as part of the SOPO (Anti-landslide Screen System) project (Grabowski, 2008).

Terracing of cultivated slopes reduces slope-wash processes considerably (Gerlach, 1976). Weathering material is delivered directly to river beds only during strong downpours and long-term rainfall via natural erosional cuts and cart roads (Slupik, 1981; Froehlich, 1982; Froehlich and Slupik, 1986). Intensification of linear erosion occurs along wood-cutting trails during intensive rainfall. Road cuts then deepen rapidly. In the Beskid Makowski Mts., following rainfall in June and September 2010, axial parts of cart roads became dissected by $30-40 \mathrm{~cm}$.

\section{Foothills}

The foothills occupy $47 \%$ of the Polish Carpathians. They are a belt of hills and intra-mountain depressions ranging from a dozen or so kilometres in width in the western part to several tens of kilometres in the east (Fig. 1A and 1C). The Carpathian Foothills rise to 300-500 $\mathrm{m}$ a.s.l. and slope via a distinct step to the north, towards the Sandomierz Basin. The region is composed of folded flysch strata. The eroded bedrock is covered by thick weathering mantles, and low foothills on the Carpathian margin are capped by loess. The middle $(50.5 \%)$ and low (31.8\%) foothills dominate, both occupying ca. $82 \%$ of the Carpathian Foothills in Poland (Margielewski et al., 2008). In this region, arable land comprises $45.5 \%$, meadows and pastures $12.7 \%$ and forests $25.4 \%$ of the area (Soja, 2002). This distribution results from settlement in the Middle Ages $\left(13-15^{\text {th }}\right.$ centuries) and deforestation, which was most intensive in the $18^{\text {th }}$ and $19^{\text {th }}$ centuries (Margielewski et al., 2008). The structure of cropland is dominated by cereals and such crops as potatoes, beetroots and corn. Farms of an average area of ca. 3 ha are usually composed of several separate fields ranging in area from 0.5 to 0.7 ha (Guzik, 1995). The division of farmland into plots requires a high density of roads $\left(7 \mathrm{~km}^{-2}\right)$, which in the foothills greatly exceeds drainage density $\left(2 \mathrm{~km}^{-2}\right)$ (Soja, 2002; Kroczak, 2010).

The physico-chemical properties of flysch strata and large thicknesses of weathering mantles are conducive to the development of landslides, the principal type of mass movement in the Carpathian Foothills (Fig. 3). Numerous small, mostly shallow, weathering and rocky-weathering landslides tend to form quite frequently. These landslides usually occur within denudation escarpments, on valley sides and in valley heads, leading to local transformation of these landforms (Kotarba, 1986; Michno, 1998; Poprawa and Raczkowski, 2003; Margielewski et al., 2008). Mass movements also induce changes in slope profiles. Initial slopes of straight convex-upwards or convex-concave-upwards profiles undergo change into slopes showing concave-upwards undulating or irregular profiles. Strong transformation of foothill ridges by mass movements results in local narrowing of interfluves and even their fragmentation into a number of separate segments (Kotarba, 1986; Michno, 1998). The succession of mass movements leads to gradual slope fragmentation and formation of small tributary valleys (Kotarba, 1986). Moreover, valleyside landslides provide source areas for delivery of weathering material for fluvial transport. Blocking of river beds by colluvium intensifies lateral erosion, leading thereby to the widening of stream beds, the steepening of their banks and the sinuous trace of the beds themselves (Kotarba, 1986; Michno, 1998; Swiechowicz, 2002; Margielewski et al., 2008).

Intensive deforestation and replacement of forested areas with crops results in a periodic absence of tight vegetation cover, which would protect the ground surface from local downpours, long-term rainfall and rapid thaws. In the Carpathian Foothills, soil susceptibility to erosion is greater, particularly in those areas where soils develop on loess. Slopewash and linear erosion on cultivated slopes result in partial or, in extreme cases, total removal of the arable layer (Fig. 3). Most of the material washed from the upper and middle parts of slopes is deposited as thick deluvial cover on flat areas or depressions within the slopes and at their feet (Swiechowicz, 2008). The annual amount of slopewash varies and depends on crop type (Table 1, Gil, 2009; Swiechowicz, 2012a, b). Slopewash also varies greatly across different crops during individual falls of rain (Table 2, Swiechowicz 2012a, b). Isolated, extreme episodes of slopewash may account for $>90 \%$ of the annual value (Gil, 2009). Long-term slopewash leads to a lowering of the slope surface and changes in its inclination, shape and length (Gil, 1999, 2009).

Table 1. Comparison of slopewash [tha $\left.{ }^{-1}\right]$ on differently used plots in Szymbark and Lazy near Bochnia in summer half-year

\begin{tabular}{|l|l|c|c|c|}
\hline \multirow{2}{*}{$\begin{array}{l}\text { Region, author, study } \\
\text { period }\end{array}$} & \multirow{2}{*}{$\begin{array}{l}\text { Crop or } \\
\text { land use }\end{array}$} & \multicolumn{3}{|c|}{$\begin{array}{c}\text { Annual values of } \\
\text { slopewash [tha-1 }\end{array}$} \\
\cline { 3 - 5 } & & min. & max. & average \\
\hline Szymbark; the boundary between & potato & 0.371 & 99.920 & 25.666 \\
the Beskid Niski Mts. and & cereal & 0.005 & 6.468 & 0.396 \\
Ciezkowice Foothills; & meadow & 0.003 & 0.346 & 0.048 \\
Gil, 2009; 1969-2000 & & & & \\
\hline Lazy near Bochnia; & potato & 0.000 & 43.396 & 21.953 \\
Carpathian Foothills margin; & cereal & 0.000 & 1.513 & 0.609 \\
Swiechowicz, 2012a, b; & meadow & 0.000 & 0.418 & 0.259 \\
2007-2009 & & & & \\
\hline
\end{tabular}


Table 2. Slopewash $\left[\right.$ tha $\left.^{-1}\right]$ on differently used plots in summer half-year during single rainfalls (Lazy near Bochnia, 2007-2009)

\begin{tabular}{|l|l|c|c|c|}
\hline \multirow{2}{*}{ Year } & \multirow{2}{*}{$\begin{array}{l}\text { Crop or } \\
\text { land use }\end{array}$} & \multicolumn{3}{|c|}{ Annual values of slopewash $\left[\mathrm{thh}^{-1}\right]$} \\
\cline { 3 - 5 } & bare fallow & 0.025 & 19.432 & 3.642 \\
& potato & 0.031 & 16.164 & 3.338 \\
& cereal & 0.000 & 0.024 & 0.002 \\
& meadow & 0.000 & 0.016 & 0.003 \\
\hline $2008^{*}$ & bare fallow & - & - & - \\
& potato & - & - & - \\
& cereal & - & - & - \\
& meadow & - & - & - \\
\hline 2009 & bare fallow & 0.000 & 96.439 & 19.056 \\
& sugar beet & 0.000 & 16.094 & 2.496 \\
& cereal & 0.016 & 0.111 & 0.017 \\
& meadow & 0.000 & 0.026 & 0.004 \\
\hline
\end{tabular}

* there were no slopewash events in 2008

During high-energy falls of rain or rapid thaws, concentration of overland flow leads to linear erosion which shapes a rill network (Fig. 7A, Swiechowicz, 2012a). These rills range from several metres to several hundred metres in length, and their courses are either straight, parallel or irregular, with a tendency to anastomose. Rills may reach several tens of centimetres in depth, locally even $2 \mathrm{~m}$. They usually concentrate along lines of natural water flow and anthropogenic landforms related to land use (e.g. along field boundaries, roads, ruts left by agricultural vehicles) (Fig. 8, Swiechowicz, 2010). Deluvial fans tend to form at the outlets of rills and ephemeral streams, merging sometimes into deluvial plains at the feet of the slopes.

The mosaic of variably cultivated fields, separated by ridges, furrows and cart roads, characteristic of the Carpathian Foothills, means that the mechanism of material delivery from slopes to river beds is complex (Gerlach, 1976; Froehlich, 1982; Swiechowicz, 2002). This material reaches valley bottoms or river beds only during downpours and long-term rains, the main role being played by cart roads close to river beds and by natural erosional cuts, with the role of footslopes being negligible (Froehlich, 1982). Most of the material is deposited upon slopes and deluvial plains situated at the feet of slopes, or is trapped by valley bottoms occupied by permanent green crops, which separate poorly interconnected slopes and river beds (Fig. 7B, Swiechowicz, 2002).

The presence of shallow landslides, intensive slopewash and linear erosion on cultivated slopes makes land management difficult, leads to considerable material losses, and frequently necessitates exclusion of vast areas from cultivation and other economic activity (such as construction).

\section{Valley and basin bottoms}

Valley bottoms and intramontane depressions, comprising 10\% of the Polish Carpathians, reveal the most dynamic relief changes (Fig. 1B). These areas are occupied by Pleistocene and Holocene meadow terraces, frequently preserved as fragments and in floodplains and river beds, as well as old and young, still developing, alluvial fans (Starkel, 1972). The rate of modelling of active fluvial landforms depends on the frequency and size of floods, amounts of material transported and grain size. Locally, valley head bottoms are modelled by landslides approaching river beds and by raised bogs located on high terraces. In recent centuries, the morphogenetic role of man has become increasingly important (Fig. 3). Longitudinal and crossprofiles of river channels are determined by type of relief of host catchment and by bedrock lithology. The parameters of channels become disturbed first due to indirect, and later direct, human impacts on water circulation, transfer of weathering material down the slopes and its further fluvial transport, which developed on a larger scale in the $19^{\text {th }}$ century. Finally, adjustment of channel geometry to changing over-bank discharge has been identified in the study area (Wyzga, 1993). The frequency of large floods has fluctuated over the last 200 years, but considerable economic losses due to such floods have greatly increased since the mid-20 ${ }^{\text {th }}$ century (Starkel et al., 2007; Lajczak, 2007b). Housing development in valley bottoms leads to further increase in such losses during floods, despite partial river regulation and construction of numerous water dams in the Carpathians (Grela et al., 1999).

The western part of the Polish Carpathians is dominated by gravelbed rivers typified by a high dynamism in channel landforms. Rivers to the east of the Dunajec River valley (Fig. 1B and 1C), draining lower topographical areas are characterized by fluvial transport restricted almost exclusively to suspended load. For this reason the upper reaches of such rivers frequently have broad channels cut into solid bedrock (Klimek, 1979).

Human-induced changes in the morphology of valley bottoms and depressions in the Polish Carpathians were initiated by deforestation, agricultural settlement and introduction of root plants. The dense network of cart roads built at that time have led, since at
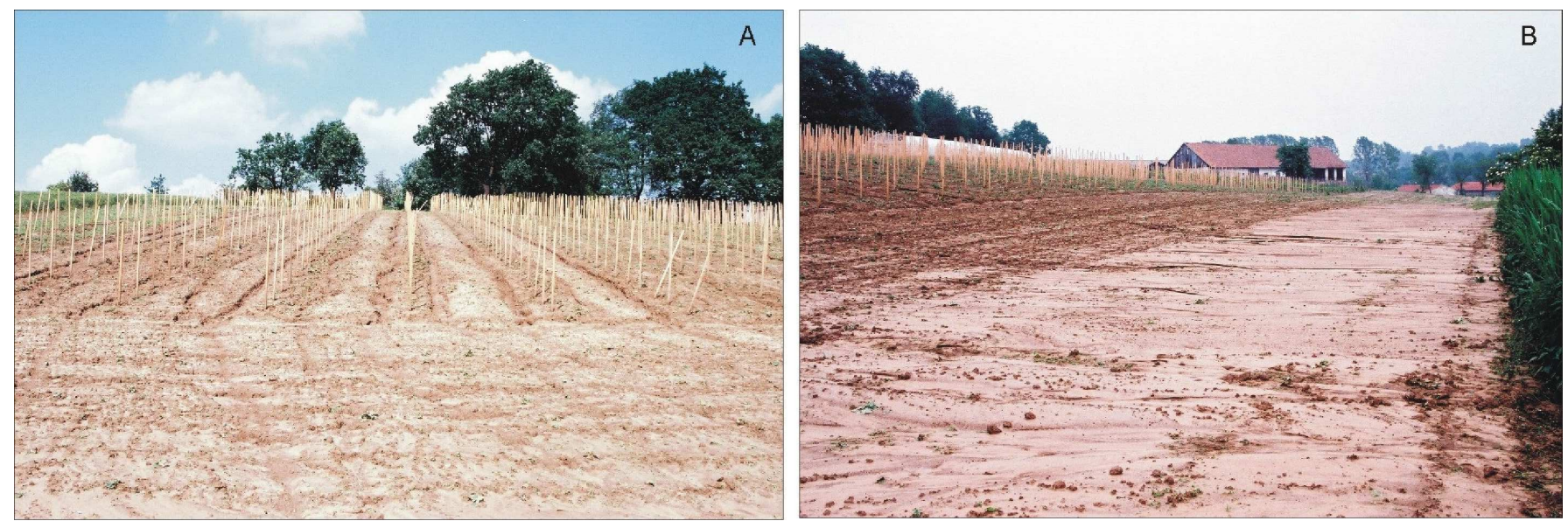

Figure 7. Soil erosion (A) and accumulation (B) on agricultural foothill slopes in Lazy near Bochnia (photo J. Swiechowicz). 

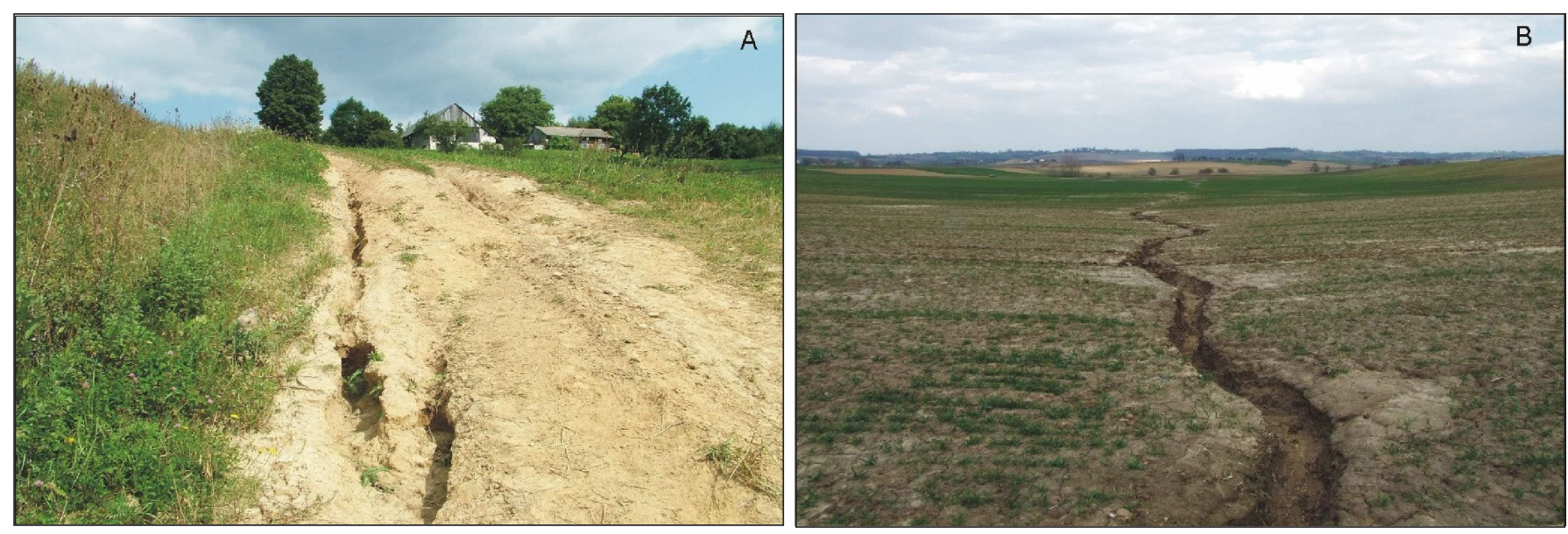

Figure 8. Development of gullies along the cart roads (A) and natural drainage lines (B) in Wieliczka Foothills (photoJ. Swiechowicz)

least the $17^{\text {th }}$ century, to intensification of outflow and increasing delivery of weathering material from slopes to river beds. In the $19^{\text {th }}$ century, mixed forests of the lower forest zone were replaced by monoculture fir forests, contributing to increased flood risk in the Carpathian valleys and higher dynamism in fluvial landforms. The dense network of forest roads built in the $19^{\text {th }}$ and $20^{\text {th }}$ centuries intensified water outflow from slopes and fostered increased delivery of weathering material into river beds. Over the past century, geomorphic changes in valley and basin bottoms have resulted chiefly from purposeful measures aiming at reducing the extent and intensity of floods as well as channel dynamism. Partial channel regulation was conducted in this period to stabilize channel banks and reduce the amount of bed load in deepened channels. Flood embankments were built along some river reaches, resulting in a narrowing of the flooded zone. Artificial water dams on large rivers, exploited since 1932, provide traps for the entire bed load and up to $99 \%$ of suspended load (Lajczak, 2006).

Increased delivery of water and weathering material from slopes to valley bottoms via the dense network of cart and forest roads, and in the case of narrow valleys directly into river beds (Froehlich, 1982) contributes to an increasing dynamism in fluvial processes. Grain size studies of bed load material point to increasing waves of floods in the western part of the Polish Beskidy Mts. as early as the $19^{\text {th }}$ century. Carrying capacity of bed load increased and thus coarsegrained material was transported (Niemirowski, 1974; Wyzga, 1993). These tendencies continued in non-regulated streams as late as the mid-20 $0^{\text {th }}$ century (Zietara, 1968). As a result, in the western part of the Polish Carpathians (including the Dunajec River valley), the dominant tendency to aggradation and broadening of river beds prevailed until the end of the $19^{\text {th }}$ century (Fig. 2). These beds were situated even higher than adjacent floodplains and underwent a transformation into broad, gravel braided channels (Klimek, 1979). On the other hand, through the $19^{\text {th }}$ century and at the beginning of the $20^{\text {th }}$, large-scale water transport of wood was carried out in headwater segments of numerous streams and rivers of the Beskidy Mts., which resulted in exposure of solid bedrock within such channels. Material removed from these sites built alluvial fans and braided channels within main river valleys. The processes leading to a shallowing and broadening of gravel river channels, lasting until the end of the $19^{\text {th }}$ century, can also be explained by climate changes during the Little Ice Age. Gravel bed shallowing in the Carpathian rivers grew in intensity in the $19^{\text {th }}$ century following the large-scale introduction of potato crops. Further downstream, over-bank sedimentation during individual floods extended beyond the active flood plain.

The channel regulation of the Carpathian rivers initiated at the turn of the $20^{\text {th }}$ century, and still continuing, replaced the previously dominant tendency of channel shallowing with channel deepening. Processes leading to channel shallowing and broadening are observed only upstream of dams. The upper river reaches, together with their tributaries, now have step-like profiles following construction of numerous stone debris-control dams. Boulder-gravel alluvial fans intercalated by silt-sandy material tend to form in shallow water dams. Gabions stabilize the channels and, in the case of broad braided channels, a narrow regulation route leads to channel deepening and narrowing and, consequently, increased river competence with regard to long-distance transport of material (Wyzga, 1993). In the lower, and even middle, reaches of the Carpathian rivers, this process is also induced by channel straightening in the lowland segments of meandering courses (Lach and Wyzga, 2002). As registered by numerous water gauges, these river segments deepened in the $20^{\text {th }}$ century by $2-3 \mathrm{~m}$, with more than $50 \%$ of this change in the second half of the 20th century. Local extraction of coarse-grained bed load led to exposure of solid bedrock within the channels (Lach and Wyzga, 2002; Krzemien, 2003; Zawiejska and Krzemien, 2004).

Increased accumulation in valley bottoms upstream of water dams results in the formation of extensive sandy and silty deltas, within which landforms previously unknown in the Carpathians develop, such as sinuous stream beds, islands, levees, interlevee basins, crevasses and crevasse splays. Deltas formed in water reservoirs tend to possess three zones: topset, foreset and bottomset. Owing to highamplitude water level changes within the reservoirs (up to $12 \mathrm{~m}$ ), longitudinal profiles of such deltas differ from those of typical Gilberttype deltas (Klimek et al., 1990; Lajczak,, 2006). The deltas continue towards the dam into the basin bottom which becomes aggraded with the finest-grained material, usually clayey. Immediately below water dams, river channels are deepened by under-loaded waters; moreover, fine-grained material is washed out from coarse-grained alluvium (Malarz, 2002).

River regulation and construction of water dams induced changes in the distribution of erosional, transporting and accumulational river bed segments in the Polish Carpathians. This distribution was previously determined by variable proportions of different kinds of bed load transport, channel gradient and catchment relief type 
(Kaszowski et al., 1976; Kaszowski and Krzemien, 1977; Klimek, 1987). Previously accumulating segments of main rivers are being eroded, while increased accumulation within water reservoirs affects former erosional or transporting river bed segments. The greatest changes in morphology of valley bottoms, induced by channel deepening in the $20^{\text {th }}$ century, occurred in the eastern part of the Polish Carpathians where, close to the Carpathian margin, former floodplains of large rivers were turned into meadow terraces as much as $9 \mathrm{~m}$ high, while newly-developing narrow floodplains underwent rapid aggradation. Gravel channels of the West Carpathian rivers, despite a higher gradient, were not deepened to such a degree and newly-formed narrow belts of floodplain became aggraded more slowly (Starkel, 2001).

The decreasing frequency of overbank water levels in the Carpathian rivers, resulting from channel deepening, does not reduce flood risk because culmination water levels tend to increase due to higher concentration and greater velocity of flood-waves (Lajczak, 2007b). At present, only infrequent, short segments of the Polish Carpathian river valleys are protected by flood embankments. The remaining segments, which in the period preceding regulation were not reached by even the highest flood-levels, are seeing at present greater losses in infrastructure caused exclusively by summer floods (Grela et al., 1999). More effective flood protection is provided by water dams, although this function frequently conflicts electricity production. This latter factor limits lowering of water levels within reservoirs during formation of flood storage (Lajczak, 2006).

In the Polish Carpathians, both fen type and raised bogs occur in the Orawa-Nowy Targ Basin, as well as in the upper San and Wolosty river valleys (Fig. 1C). Peatbog extent has been greatly reduced, since at least the $18^{\text {th }}$ century, owing to extraction and burning of peat and post-peat extraction areas are increasing. These areas include exploitation escarpments, peat remnants, post-exploitation depressions and draining ditches. Sites at which peat was completely extracted saw the exposure of the mineral substratum bearing palaeo-channels, where peat-forming processes initially began (Lajczak, 2007a). Peat exploitation was largely restricted after 1990, leading to a revitalization of the preserved fragments of peat domes and post-peat areas. Anthropogenically degraded peat bogs witness the overgrowing and shallowing of draining ditches, flattening of escarpments left following exploitation due to sliding and liquefaction of peat layers, and filling and overgrowing of post-exploitation depressions. As a result of progressive wetting of the preserved fragments of peat domes, transformation of peat into peat earth proceeds in successively smaller areas, and increased wetting turns post-peat areas into secondary edge around the preserved parts of peat domes. Encroachment of peat vegetation upon the domes and surrounding edge protects these areas from erosion, and a renewed process of peat accumulation begins.

\section{Conclusions}

Mutual interactions between man and recent geomorphic processes are a fundamental feature of the recent evolution of the Polish Carpathians. The only exceptions are in high-mountain areas where human impact is minor.

Landsliding in the Polish Flysch Carpathians, usually involves slope cover. It, is currently a principal process in slope transformation and that poses the most serious threat to man, both in the mountains and the foothills. On the other hand, poorly located housing on slopes initiates mass movements, frequently with catastrophic consequences.
Deforestation and land use have over the past 200 years fostered intensive slopewash and linear erosion which played an important role in shaping foothill relief. Extreme processes of slopewash and linear erosion on cultivated slopes usually lead to economic losses in agriculture.

Different dynamic types of river longitudinal profile and floodplain formation coexist in the Carpathians. Following changes in land use and channel regulation initiated at the beginning of the $20^{\text {th }}$ century, a tendency to river bed deepening prevails. Moreover, floods, and not only extreme instances, continue to pose a threat to man, with their effects enhanced by housing in floodplain areas.

A tendency to reduction of arable land and an increase in grassland and forest area, observed over the past two decades, will lead to a gradual limitation of slope-wash and wind erosion as well as a simultaneous increase in linear erosion on slopes and river bed deepening, and activation of shallow landslides. Because, following the Second World War there was no permanent collectivization of land in the Polish Carpathians, in contrast to the other parts of the Carpathian chainthe relationships described between geomorphic processes and human activity cannot be applied directly to Carpathian regions in other countries.

\section{References}

Adamczyk, M.J., 1978, Changes in landscape of the Polish Carpathians in years 1650-1870: Wierchy, v. 47, pp. 20-24, (in Polish).

Bajgier-Kowalska, M., 2004, The role of the human activity in the incidence and reactivation of landslides in the flysch Carpathians: Folia Geographica, series Geographica-Physica v. 36-36, pp. 11-30, (in Polish with English summary).

Bajgier-Kowalska, M. and Zietara, T., 2002, Succession of the mass movements during last 5-years in the Flysch Carpathians: Problemy Zagospodarowania Ziem Gorskich, v. 48, pp. 31-42, (in Polish with English summary).

Birkenmajer, K., 1986, Outline of the geological evolution of the Pieniny Klippen Belt: Przeglad Geologiczny, v. 34, no. 6, pp. 293-304, (in Polish).

Bravard, J.P. and Petts, G.E., 1996, Human impacts on fluvial hydrosystems, in Petts, G.E., Amoros, C., eds, Fluvial Hydrosystems: Chapman and Hall, London, pp. 242-262.

Brookes, A., 1988, Channelised rivers: Chichester, Wiley, 342 pp.

Bucala, A., 2012, Wspolczesne zmiany srodowiska przyrodniczego dolin potokow Jaszcze i Jamne w Gorcach: Prace Geograficzne Instytutu Geografii i Przestrzennego Zagospodarowania PAN, v. 231, 145 pp., (in Polish with English summary).

Czochanski, J.T., 2000, Influence of tourism on erosional-denudational processes and forms in surrounding of tourist paths in Borowiak, D., Czochanski, J.T., eds, Z badan geograficznych w Tatrach Polskich: Wydawnictwo Uniwersytetu Gdanskiego, Gdansk, pp. 341-348, (in Polish).

Dlugosz, Z. and Soja, M., 1995, Population in Warszynska, J., ed., Karpaty Polskie: Uniwersytet Jagiellonski, Krakow, pp. 209-215, (in Polish with English summary).

Froehlich, W., 1982, The mechanism of fluvial transport and the waste supply into the stream channel in a mountainous flysch catchment: Prace Geograficzne Instytutu Geografii i Przestrzennego Zagospodarowania PAN, v. 143, 144 pp., (in Polish with English summary).

Froehlich, W. and Slupik, J., 1986, The role of roads in the generation of flow and erosion in the Carpathian flysch drainage basins: Przeglad Geograficzny, v. 58, no. 1-2, pp. 129-160, (in Polish with English summary).

Gadek, B., Raczkowska, Z. and Zogala, B., 2009, Debris slope morphodynamics as a permafrost indicator in zone of sporadic permafrost, High-Tatras, Slovakia: Zeitschrift fur Geomorphologie N.F., v. 53, Suppl. 3, pp. 79-100.

Gerlach, T., 1966, Developpement actuael des versants dans le Basin du Haut Grajcarek, Hautes Beskides, Carpates Occidentales: Prace Geogr. 
Instytutu Geografii PAN, v. 52, 124 pp., (in Polish with French summary). Gerlach, T., 1976, Present-day slope development in the Polish flysch Carpathians. Prace Geograficzne Instytutu Geografii i Przestrzennego Zagospodarowania PAN, v. 122, 116 pp., (in Polish with French summary)

Gil, E., 1999, Water circulation and wash down on the flysch slopes used for farming purposes in 1980-1990: Zeszyty Instytutu Geografii i Przestrzennego Zagospodarowania PAN, v. 60, 78 pp., (in Polish with English summary).

Gil, E., 2009, Extreme values of soil downwash on cultivated slopes in the Polish Flysch Carpathians in Bochenek, W. and Kijowska, M., eds, Funkcjonowanie srodowiska przyrodniczego $\mathrm{w}$ okresie przemian gospodarczych w Polsce: Biblioteka Monitoringu Srodowiska, Szymbark, pp. 191-218, (in Polish with English summary).

Gilewska, S., 1986, The geomorphological subdivision of Poland: Przeglad Geograficzny, v. 58, pp. 15-42, (in Polish with English summary).

Gorczyca, E., 2004, The transformation of flysch slopes by catastrophic rainfall-induced mass-processes (Lososina River catchment basin): Wydawnictwo Uniwersytetu Jagiellonskiego, Krakow, 101 pp., (in Polish with English summary)

Goudie, A., 2006, The human impact on the natural environment: past, present and future: Blackwell, Oxford, $347 \mathrm{pp}$.

Grabowski, D., 2008, The SOPO Anti-landslide Screen System: Przeglad Geologiczny, v. 56, pp. 537-538, (in Polish).

Gregory, K.J., 2006, The human role in changing river channels: Geomorphology, v. 79, pp. 172-191.

Grela, J., Slota, H. and Zielinski, T., eds, 1999, The Vistula river catchement, monograph of flood in July 1997: Instytut Meteorologii i Gospodarki Wodnej, Warszawa, (in Polish).

Guzik, C., 1995, Agricultural land use in Warszynska, J., ed., Karpaty Polskie: Uniwersytet Jagiellonski, Krakow, pp. 239-252, (in Polish with English summary).

Izmailow, B., 1984, Eolian process in alpine belt of the High Tatra Mts., Poland: Earth Surfaces Processes and Landform, v. 9, pp. 143-151.

Jahn, A., 1958, Periglacial microrelief in the Tatras and Babia Gora Massif: Biuletyn Peryglacjalny, v. 4, pp. 227-249, (in Polish).

Jahn, A., 1979, On Holocene and present-day morphogenetic processes in the Tatra Mountains: Studia Geomorphologica Carpatho-Balcanica, v. 13, pp. 111-129.

Jankowski L., Margielewski W., 2012. Rozwoj rzezby Karpat zewnetrznych w aspekcie ewolucji basenowo-tektonicznej gorotworu karpackiego in T. Karcz, K. Buczek (Eds.) Strukturalne i litofacjalne uwarunkowania rozwoju rzezby polskich Karpat zewnetrznych: Beskid Niski-Beskid Sadecki-Babia Gora. Materialy III Warsztatow Geomorfologii Strukturalnej, Dukla-Piwniczna-Zawoja, 25-28 wrzesnia 2012:11-19 (in Polish).

Kacprzak, A., 2002-2003, Slope deposits as a subject of geomorphological and pedological studies: Folia Geographica, series Geographica-Physica, v. 33-34, pp. 27-37, (in Polish with English summary).

Kaszowski, L., 1973, Morphological activity of the mountain streams: Zeszyty Naukowe Uniwersytetu Jagiellonskiego, Prace Geograficzne, v. 31, pp. 1-100.

Kaszowski, L. and Krzemien, K., 1977, Structure of mountain channel systems as exemplified by chosen Carpathian streams: Studia Geomorphologica Carpatho-Balcanica, v. 11, pp. 111-125.

Kaszowski, L., Krzemien, K. and Libelt, P., 1988, Postglacial modelling of glacial cirques in the Western Tatras: Zeszyty Naukowe Uniwersytetu. Jagiellonskiego, Prace Geograficzne, v. 71, pp. 121-141.

Kaszowski, L., Niemirowski, M. and Trafas, K., 1976, Problems of the dynamic of river channels in the Carpathian part of the Vistula basin: Zeszyty Naukowe Uniwersytetu Jagiellonskiego, Prace Geograficzne, v. 43 , pp. $7-37$

Klimek, K., 1979, Morphodynamic channel types of the Carpathian tributaries to the Vistula: Folia Geographica, series Geographica-Physica, v. 12, pp. 35-47, (in Polish with English summary).

Klimek, K., 1987, Man's impact on fluvial processes in the polish Western Carpathains: Geografiska Annaler, v. 69A, pp. 221-226.

Klimek, K., Lajczak, A. and Zawilinska, L., 1990, Sedimentary environment of the modern Dunajec delta in artificial Lake Roznow, Carpathian Mts.,
Poland: Quaestiones Geographicae, v. 11/12, pp. 81-92

Klimek, K. and Trafas, K., 1972, Young-Holocene changes in the course of the Dunajec river in the Beskid Sadecki Mountains: Studia Geomorphologica Carpatho-Balcanica, v. 6, pp. 85-92.

Kotarba, A., 1970, The morphogenetic role of the foehn wind in the Tatra Mts.: Studia Geomorphologica Carpatho-Balcanica, v. 4, pp. 171-187.

Kotarba, A., 1971, Coarse and intensity of present-day superficial chemical denudation in the Western Tatra Mts.: Studia Geomorphologica CarpathoBalcanica, v. 5, pp. 111-127.

Kotarba, A., 1986, The role of landslides in modelling of the Beskidian and Carpathian Foothills relief: Przeglad Geograficzny, v. 58, pp. 119-129, (in Polish with English summary).

Kotarba, A., 1989, Landslides: Extent and Economic Significance in Central Europe in Brabb, E. and Harrod, B.L., eds., Landslides: extent and economic Significance: Proceedings $28^{\text {th }}$ IGU Congress: Symposium on landslides, Washington: Balkema, Rotterdam, pp. 191-202.

Kotarba, A., 1992, High energy geomorphic events in the Polish Tatra Mountains: Geografiska Annaler, v. 74A, pp. 123-131.

Kotarba, A., 1995, Rapid mass wasting over the last 500 years in the High Tatra Mountains: Questionaes Geographicae, spec. issue, v. 4, pp.177183.

Kotarba, A., 1997, Formation of High-Mountain Talus Slopes Related to Debris-Flow Activity in the High Tatra Mountains: Permafrost and Periglacial Processes, v. 8, pp. 191-204.

Kotarba, A., 1999, Geomorphic effect of catastrophic summer flood of 1997 in the Polish Tatra Mountains: Studia Geomorphologica CarpathoBalcanica, v. 33, pp.101-115.

Kotarba, A., Kaszowski, L. and Krzemien, K., 1987, High-mountain denudational system in the Polish Tatra Mountains: Prace Geograficzne Instytutu Geografii i Przestrzennego Zagospodarowania PAN, spec. Issue, v. 3, $106 \mathrm{pp}$.

Kozak, J., Estreguil, C. and Troll, M., 2007, Forest cover changes in the northern Carpathians in the $20^{\text {th }}$ century: a slow transition: Journal Land Use Science, v. 2, pp.127-146.

Kroczak, R., 2010, Geomorphological and hydrological effects of unmetalled road network functioning on the example of Ciezkowice Foothills: Prace Geograficzne Instytutu Geografii i Przestrzennego Zagospodarowania PAN, v. 225, $138 \mathrm{pp}$.

Krzemien, K., 1991, Dynamics of the high-mountain fluvial system with the Western Tatra Mts. as example: Rozprawy habilitacyjne Uniwersytetu Jagiellonskiego, v. 215, 160 pp., (in Polish with English summary).

Krzemien, K., 2003, The Czarny Dunajec river, Poland, as example of humaninduced development tendencies in a mountain river channel: Landform Analysis, v. 4, pp. 57-64

Ksiazkiewicz, M., 1972, Carpathians in Pozaryski, W., ed., Budowa Geologiczna Polski, v. 4, Tektonika, part. 3: Wydawnictwa Geologiczne, Warszawa, 228 pp., (in Polish).

Lach, J. and Wyzga, B., 2002, Channel incision and flow increase of the upper Wisloka River, southern Poland, subsequent to the reafforestation of its catchment: Earth Surface Processes and Landforms, v. 27, pp. 445462 .

Lajczak, A., 2002, Slope Remodelling in Areas Exploited by Skiers: Case Study of the Northern Flysch Slope of Pilsko Mountain, Polish Carpathian Mountains, in Allison R.J., ed., Applied Geomorphology: John. Wiley \& Sons, Ltd., Chichester, pp. 91-100.

Lajczak, A., 2006, Deltas in dam retained lakes in the Carpathian part of the Vistula drainage basin: Prace Geograficzne Instytutu Geografii i Gospodarki. Przestrzennej Uniwersytetu Jagiellonskiego, v. 116, pp. 99-109.

Lajczak, A., 2007a, Natura 2000 in Poland, Area PLH120016 The OrawskoPodhalanskie Peatlands: Institute Botany, Polish Academy of Sciences, Kraków, 139 pp.

Lajczak A. 2007b, River training vs flood risk in the upper Vistula basin, Poland: Geographia Polonica, v. 80(2), pp. 79-96.

Malarz, R., 2002, Flood transformation of coarse-grained alluvium in gravelbed rivers of the West Flysch Carpathians (as exemplified by the Sola and Skawa rivers): Prace Monograficzne Akademii Pedagogicznej w Krakowie, v. 335, 146 pp., (in Polish with English summary).

Margielewski, W., Swiechowicz, J., Starkel, L., Lajaczk, A. and Pietrzak, M., 
2008, Recent evolution of the Flysch Carpathians relief, in Starkel, L., Kostrzewski, A., Kotarba, A. and Krzemien, K., eds, Wspolczesne przemiany rzezby Polski: Instytut Geografii i Gospodarki Przestrzennej Uniwersytetu Jagiellonskiego, Krakow, pp. 57-133, (in Polish).

Messerli, B., Grosjean, M., Hofer, T., Nunez, L. and Pfister, C., 2000, From nature-dominated to human-dominated environmental changes, in Alverson, K.D. et al., eds, Past global changes and their significance for the future: Elsevier, Amsterdam, pp. 459-479.

Michno, A., 1998, Types of landslides and their geomorphological role in the Carpathian foothills marginal zone between the Raba and Uszwica Rivers, in Chelmicki, W., ed., The Carpathian footlills marginal zone. Man and Environment: Prace Geograficzne Instytutu Geografii i Gospodarki Przestrzennej Uniwersytetu Jagiellonskiego, v. 103, pp. 45-60.

Mirek, Z., 1996, Anthropogenic threats and changes of nature in Mirek, Z., ed., Nature of the Tatra National Park: Tatrzanski Park Narodowy, Krakow-Zakopane, pp. 595-617, (in Polish with English summary).

Mirek Z., Piekos-Mirek H., 1979. Influence of tourism on plant cover in the Tatra Mountains. Wierchy, v. 48, pp. 160-175.

Moscicki, J. and Kedzia, S., 2001, Investigation of mountains permafrost in the Kozia Dolinka valley, Tatra, Mountains, Poland: Norsk Geografisk Tidsskrift, v. 55, pp. 235-240.

Nemcok, A., 1982, Slope movements in the Slovak Carpathians: Veda, Bratislava, 319 pp., (in Slovak with English summary).

Niemirowski, M., 1974, The dynamics of contemporary river beds in the mountain streams: Zeszyty Naukowe Uniwersytetu Jagiellonskiego, Prace Geograficzne, v. 34, 97 pp.

Nir, D., 1983, Man, a geomorphological agent: an introduction to anthropic geomorphology: Jerusalem, Keter, $165 \mathrm{pp}$.

Nowak, A., 2012, Transformation of the forest-field boundary in the Pasma Magurskie (Beskid Niski Mts) from 1978-1980 to 2003-2004: Prace Geograficzne, v. 128, pp. 109-122, (in Polish with English summary).

Ostafin, K., 2009, Zmiany granicy rolno-lesnej w srodkowej czesci Beskidu Sredniego od polowy XIX wieku do 2005 roku: Wydawnictwo UJ, Krakow, 118 pp (in Polish).

Oszczypko, N., 1995, Geology in Warszynska, J., ed., Karpaty polskie, Uniwersytet Jagiellonski, Krakow, pp. 15-22, (in Polish).

Oszczypko, N., Golonka, J. and Zuchiewicz, W., 2002, The landslide at Lachowice (Western Outer Carpathians, Poland): effects of catastrophic flood in 2001: Przeglad Geologiczny, v. 50, no 10, pp. 893-898, (in Polish with English summary).

Oszczypko, N., Uchman, A. and Malata, E., eds., 2006, Palaeotectonic development of the Outer Carpatnians and the Pieniny Klippen Belts: Instytut Nauk Geologicznych, Uniwersytet Jagiellonski, 199 pp., (in Polish with English summary).

Poprawa, D. and Raczkowski, W., 2003, Carpathian landslide (southern Poland): Przeglad Geologiczny, v. 51, pp. 685-692, (in Polish with English summary).

Raczkowska, Z., 1995, Nivation in the High Tatras, Poland: Geografiska Annaler, v. 77A, pp. 251-258.

Raczkowska, Z., 2008, Recent evolution of the Tatra Mts. relief in Starkel, L., Kostrzewski, A., Kotarba, A. and Krzemien, K., eds., Wspolczesne przemiany rzezby Polski: Instytut Geografii i Gospodarki Przestrzennej Uniwersytetu Jagiellonskiego, Krakow, pp. 36-56, (in Polish).

Raczkowska, Z., Lajczak, A., Margielewski, W. and Swiechowicz, J., 2012, Recent landform evolution in the Polish Carpathians in Loczy, D., Stankoviansky, M. and Kotarba A., eds, Recent Landform Evolution. The Carpatho-Balkan-Dinaric Region: Springer, Dordrecht, pp. 47-101.

Remondo, J., Soto, J., Gonzalez-Díez, A., Diaz de Teran, J.R. and Cendrera, A., 2005, Human impact on geomorphic processes and hazards in mountain areas in northern Spain: Geomorphology, v. 66, no 1-4, pp. 69-84.

Slaymaker, O., 2010, Driver of mountain landscape change during the twentyfirst century: Journal of Soils Sediments, v. 10, pp. 597-610, DOI 10.1007/ s11368-010-0194-6.

Slaymaker, O. and Embleton-Hamann, Ch., 2009, Mountains in
Geomorphology and Global Environmental Change: Cambridge University Press, Cambridge, pp. 37-61.

Slupik, J., 1981, Role of slope in generation of runoff in the Flysh Carpathian: Prace Geograficzne Instytutu Geografii i Przestrzennego Zagospodarowania PAN, v. 142, 98 pp., (in Polish with English summary).

Soja, R., 2002, Hydrological aspects of anthropopression in the Polish Carpathians: Prace Geograficzne Instytutu Geografii i Przestrzennego. Zagospodarowania PAN, v. 186, 130 pp., (in Polish with English summary)

Starkel, L., 1960, The development of the flysch Carpathians relief during the Holocene: Prace Geograficzne Instytutu Geografii PAN, v. 22, 239 pp., (in Polish with English summary).

Starkel, L., 1972, An outline of the relief of the Polish Carpathians and its importance for human management: Problemy Zagospodarowania Ziem Gorskich, v. 10, pp. 75-150, (in Polish with English summary).

Starkel, L., 2001, Evolution of the Vistula river valley since the last glaciation till present: Monografie Geograficzne Instytutu Geografii i Przestrzennego Zagospodarowania PAN, v. 2, pp. 1-263, (in Polish with English summary).

Starkel, L., Pietrzak, M. and Lajczak, A., 2007, Impact of land-use changes and increasing frequency of heavy rainfall on circulation of water, soil erosion and protection of natural resources in the Carpathians: Problemy Zagospodarowania Ziem Gorskich, v. 54, pp. 19-30, (in Polish with English summary).

Swiechowicz, J., 2002, Linkage of Slope Wash and Sediment and Solute Export from a Foothill Catchment in the Carpathian Foothills of South Poland: Earth Surface Processes and Landforms, v. 27, no. 12, pp. 13891413.

Swiechowicz, J., 2008, Soil erosion on cultivated foothill slopes during extreme rainfall events in Wisnicz Foothills of southern Poland: Folia Geographica, series Geographica Physica, v. 39, pp. 80-93.

Swiechowicz, J., 2010, Extreme sheet and rill erosion on agricultural slopes in the flysch Polish Carpathians in Smolska, E. and Rodzik, J., eds., Procesy erozyjne na stokach uzytkowanych rolniczo (metody badan, dynamika i skutki): Prace i Studia Geograficzne WGSR UW, v. 45, pp. 29-48, (in Polish with English summary).

Swiechowicz, J., 2012a, Rainfall thresholds. for erosion processes in agricultural catchments: Instytut Geografii i Gospodarki Przestrzennej UJ, Krakow, 282 pp., (in Polish with English summary).

Swiechowicz, J., 2012b, Water erosion on agricultural foothill slopes (Carpathian Foothills, Poland): Zeitschrift für Geomorphologie, v. 56 (Suppl.), no 3, pp. 21-35.

Wohl, E., 2006, Human impacts to mountain streams, Geomorphology, v. 79 , pp. $217-248$.

Wolski J., 2007, Przeksztalcenia krajobrazu wiejskiego Bieszczadów Wysokich w ciagu ostatnich 150 lat: Prace Geograficzne Instytutu Geografii i Przestrzennego Zagospodarowania PAN, v. 214, 228 pp., (in Polish with English summary).

Wyzga, B., 1993, River response to channel regulation: case study of the Raba River, Carpathians, Poland: Earth Surface Processes and Landforms, v. 18 , pp. 541-556.

Zawiejska, J. and Krzemien, K., 2004, Man-induced changes in the structure and dynamic of the upper Dunajec river channel: Geograficky Casopis, v. 56 , no 2, pp. 111-124.

Zietara, T., 1968, Part played by torrential rains and floods on the relief of Beskid Mountains: Prace Geograficzne Instytutu Geografii PAN, v. 60, 116 pp., (in Polish with English summary).

Zietara, T., 1969, On classification of landslides in the Western Beskids: Studia Geomorphologica Carpatho-Balcanica, v. 3, pp. 111-131, (in Polish with English summary).

Zytko, K., Zajac, R., Gucik, S., Rylko, W., Oszczypko, N., Garlicka, I., Nemom, J., Elias, M., Mencik, E. and Stranik, Z., 1989, Map of the tectonic elements of the Western Outer Carpathians and their foreland 1:500 000 in Poprawa, D. and Nemcok, J., eds., Geological Atlas of the Western Outer Carpathians and their Foreland: Panstwowy Instytut Geologiczny, Warszawa. 